Princz Adrienn ${ }^{1}$

\title{
Civilben a munkahelyi egészségért ${ }^{2}$
}

\author{
Working as a Civilian for Workplace Health
}

\section{Absztrakt}

A munkahelyi egészségfejlesztés az egyik olyan lehetösége a hazai munkaerőpiacnak, ahol hangsúlyosabbá válik annak a megállapitásnak a tartalma, miszerint „a korszerü vállalat alapvető értéke az ember, a munkatársak egészsége pedig jelentös érték, cél és komoly erőforrás a gazdasági szereplők jelenlegi és jövőbeni müködése szempontjából". ${ }^{3}$ Az Egészségügyi Világszervezet (WHO) már 2003-ban deklarálta, hogy a rendszeres testmozgás, külön kitérve a munkahelyi egészségfejlesztő programokra is, milyen gazdasági jelentöséggel rendelkezik. ${ }^{4}$ Jelen tanulmányban átfogóan vizsgálom meg ennek a kérdéskörnek a helyzetét, egy szegedi székhelyü civil szervezet bemutatásán keresztül.

Kulcsszavak: civil szervezet, munkahelyi egészségfejlesztés, jóllét, statisztika

\section{Abstract}

Workplace programs to improve health through physical activity constitute one of those possibilities of the Hungarian labour market, where the substance of the following statement becomes more emphatic: "Humans constitute the fundamental value of a modern corporation, and the health of the co-workers is an important value, purpose, as well as a serious resource for both the present and future functioning of all economic

Szegedi Tudományegyetem Állam- és Jogtudományi Kar Statisztikai és Demográfiai Tanszék, egyetemi tanársegéd - University of Szeged Faculty of Law and Political Sciences, Department of Statistics and Demography, Assistant Professor, e-mail: princz@juris.u-szeged.hu ORCID: https://orcid.org/0000-0002-6866-8272.

2 Jelen tanulmány a 2017. szeptember 29-én, Debrecenben megrendezett „A globalizáció és a változás hatása az emberi erőforrás menedzsment funkcióira" tudományos konferencián és szakmai fórumon megtartott előadás tanulmány formájában megjelent változata.

3 Erdőzö-Horváth Krisztina: Rekreáció (és) Akadémia, rekreacio.eu, 2 (2012/2) 3.

4 Health and Development through Physical Activity and Sport, World Health Organisation, 2003, http://apps.who.int/ iris/bitstream/10665/67796/1/WHO_NMH_NPH_PAH_03.2.pdf (Letöltve: 2017. 08. 29.) 
operators." The World Health Organization (WHO) has declared already in 2003, that regular physical activity has a serious economic effect, including workplace health improvement programs. In this paper l analyse the status of these issues comprehensively, through the introduction of a Szeged-based NGO.

Keywords: NGO, health promotion at the workplace, well-being, statistics

„[...] a hosszabb és jobb minőségü élethez a mindennapi viselkedés tartós megváltoztatása a kulcs. Ennek részeként változtatnunk kell étkezési szokásainkon és mozgáshiányos életmódunkon. A viselkedésváltozást nem adják receptre." ${ }^{5}$

Brian Wansink

\section{Bevezetés}

Anima sana in corpore sano - azaz "ép testben ép lélek". Az ismert latin közmondás tartalma és üzenete tiszta, világos és érthető. Nem véletlen, hogy az ismert cipőmárka alapítója is ezt választotta nemcsak cégének filozófiájául, hanem egyszersmind cége nevének is. ${ }^{6}$ Ugyanakkor, ha a mindennapok tapasztalatai alapján e mondás tartalmát átgondoljuk, akkor talán pontosabb lenne úgy a megfogalmazása, hogy „ép testben épphogy élek?"

Korunkat alapvetően „3 nagy robbanás” jellemzi: a népesség-, a hosszabb életüség és az információrobbanás". "Örvendetes módon nemcsak hazánkban, de uniós, sőt világszinten is folyamatosan növekszik a születéskor várható élettartam, és bár tovább élünk, mint elődeink, felmerül a kérdés, hogy vajon ezzel a tendenciával egyszersmind a jobb életminőség is együtt jár-e? Vajon csak az egyén felelőssége és érdeke, hogy szabadidejében saját egészségével foglalkozzon, vagy esetleg érdekelt lehet-e például az egyén munkáltatója is ebben, hiszen időnk legnagyobb részét munkában vagy munkával töltjük.

Alaptörvényünk O) cikke ${ }^{8}$ deklarálja, hogy mindenki felelős önmagáért, ami természetesen nemcsak a közösségi feladatokhoz való megfelelö mértékü anyagi és egyéb hozzájárulásban csúcsosodhat ki, hanem abban is, hogy mindenki mindent megtesz azért, hogy testi és lelki egészsége megfelelő legyen, akár a munkahelyen is. Különösen fontos ez azért is, mert Alaptörvényünk a XX. cikkben ${ }^{9}$ azt is kimondja,

Wansink, Brian: Evés ész nélkül, HVG, Budapest, 2014, 208.

ASICS History, https://corp.asics.com/en/about_asics/history (Letöltve: 2019. 10. 04.)

Iván László: Az idősödés és időskor, mint az edzettség próbája, in: Némethné Jankovics Györgyi (szerk.), Aktivitás - Mozgás - Sport a harmadik életszakaszban, Szenior könyvek, Győr, 2005, 7.

8 Magyarország Alaptörvénye, O) cikk: „Mindenki felelős önmagáért, képességei és lehetőségei szerint köteles az állami és közösségi feladatok ellátásához hozzájárulni.”

9 Magyarország Alaptörvénye, XX) cikk: „(1) Mindenkinek joga van a testi és lelki egészséghez.

(2) Az (1) bekezdés szerinti jog érvényesülését Magyarország genetikailag módositott élőlényektől mentes mezőgazdasággal, az egészséges élelmiszerekhez és az ivóvízhez való hozzáférés biztosításával, a munkavédelem és az egészségügyi ellátás megszervezésével, a sportolás és a rendszeres testedzés támogatásával, valamint a környezet védelmének biztosításával segíti elő." 
hogy az állam mindezeket a célokat a sportolás és rendszeres testedzés támogatásával hivatott elérni.

$\mathrm{Az}$ (1) bekezdés szerinti jog érvényesülését Magyarország genetikailag módosított élőlényektől mentes mezőgazdasággal, az egészséges élelmiszerekhez és az ivóvízhez való hozzáférés biztosításával, a munkavédelem és az egészségügyi ellátás megszervezésével, a sportolás és a rendszeres testedzés támogatásával, valamint a környezet védelmének biztosításával segíti elő.

Az ember mind fizikai, mind mentális egészségének a fenntartása kiemelten fontos a hon-, illetve a rendvédelem területén dolgozók számára is. „A katonai védelmi szektor hatékony múködése szempontjából a megelőzésnek óriási szerepe van a személyi állomány indokolatlan és idő előtti elhasználódása, felesleges túlterhelése, a foglalkozási ártalmak kialakulása elleni fellépésben, de a helyes mentálhigiénés és megfelelő erőnléti állapot fenntartásában, a katonai feladatokhoz, a függelmi viszonyokhoz, a terhelések vállalásához való viszony helyes értékeinek ápolásában, a feladatok iránti motivációk kialakításában egyaránt."10

Jelen tanulmányomban a témával kapcsolatos több kérdést szeretnék megvizsgálni. Ilyen például a szabadidő, illetve a szabadidő-felhasználás, valamint a munkahelyi egészségfejlesztés terminológiai meghatározása. Mindezeket kiegészítve kitérek egy olyan tanulmány föbb megállapításaira is, amely a munkahelyi egészségfejlesztés európai gyakorlatát vizsgálta.

Mivel jelen munka fókuszpontjában annak a lehetséges kérdésnek a vizsgálata áll, hogy egy nonprofit szervezet lehet-e részese a munkahelyi egészségfejlesztésnek, ennek érdekében megvizsgálom, hogy mit is értünk civil szféra alatt, továbbá kitérek arra, hogy milyen mértékben kapcsolódnak a sport, az egészségfejlesztés, illetve a rekreáció területéhez.

Mindezek alapján felmerül a kérdés, hogy egy civil szervezet biztosít-e lehetőséget az érintettek, illetve az érdeklődők számára a rekreáció változatos formáinak megismertetésében? Ehhez rendelkezik-e továbbá megfelelő szakmai háttérrel?

Mindezekkel összefüggésben, röviden kitérek annak a vizsgálatára is, amit az alapvető szakmai és tudományos eredményeken alapuló értékek átadása jelenthet a gazdasági élet számára. ${ }^{11}$

Munkám során a rendelkezésre áló, átvett statisztikai adatok segítségével igyekszem alátámasztani a megállapításaimat.

10 Sótér Andrea: A munkahelyi egészségfejlesztési tevékenységek rendszerének kialakulása és gyakorlata a Magyar Honvédségben, Honvédorvos, 69 (2017/3-4) 22. http://real.mtak.hu/93500/1/02\%20A\%20munkahelyi\%20eg\%C3\%A9szs\%C3\%A9gfejleszt\%C3\%A9si\%20tev\%C3\%A9kenys\%C3\%A9g\%20rendszer\%C3\%A9nek\%20kialak\%C3\%ADt\%C3\%A1sa\%20 \%C3\%A9s\%20gyakorlata\%20a\%20Magyar\%20Honv\%C3\%A9ds\%C3\%A9gben.pdf (Letöltve: 2020. 03. 26.)

11 Vö.: Bucher Eszter: Változó civil társadalom, Nonprofit szervezetek az ezredforduló után, Acta Sociologica: Pécsi Szociológiai Szemle: Szociológiai Tudományos Szemle, 5 (2012/1) 143-150. http://szociologia.btk.pte.hu/sites/default/files/ Acta_Sociologia/20_-_bucher.pdf (Letöltve: 2017. 08. 25.) 


\section{Szabadidő-felhasználás}

A rendelkezésünkre álló idő beosztására több tényező is hat, de alapvetően az általunk végzett munka az, amely a felhasználására vonatkozó irányt meghatározza: hol, milyen környezetben, milyen munkafeltételek mellett dolgozunk? Milyen típusú munkakört töltünk be? Naponta akár több órát is utazunk a munkahelyünkre, vagy beérünk rövidebb idő alatt? Fizikai vagy szellemi munkát végzünk? És még lehetne sorolni azokat a kérdéseket, amelyek ily módon alapjaiban határozzák meg életmódunkat és a hozzá tartozó időfelhasználásunkat. ${ }^{12}$

Éppen ezért arra vonatkozóan, hogy mit is értünk szabadidő alatt, a szakirodalom abban a kérdésben képvisel csupán egységes álláspontot, hogy nincs mindenki vagy legalábbis a többség által elfogadott fogalmi meghatározás.

Dumazedier meghatározása szerint „a szabadidő olyan elfoglaltságok együttese, amelynek az egyén teljes kedve szerint átadhatja magát, akár, hogy pihenhessen, akár, hogy szórakozhasson, akár, hogy fejleszthesse önkéntes társadalmi résztvételét, érdek nélküli tájékozódását, vagy képzését, miután megszabadult minden hivatásbeli családi vagy társadalmi kötöttségétől."13

Richard Peterson definíciója a negatív szúkítés mentén haladva lényegében kizárja azokat a tényezőket, amelyek véleménye szerint nem tartoznak a szabadidő rendszerébe. „Peterson (idézi Vitányi, 2001) definíciója szerint szabadnak nevezzük azt az időt, amelyben nem végzünk fizetett munkát, a családdal és a háztartással kapcsolatos feladatokat, nem intézünk személyes ügyeket és nem alszunk."14

„Max Kaplan (idézi Vitányi, 2001) pedig hét dolgot nevezett meg a szabadidővel kapcsolatban: a munka ellentéte, kellemesség, önkéntes társadalmi munka, a szabadság pszichológiai érzékelése, kultúra, nem fontos dolgokkal való foglalkozás, játék."15

Szántó Miklós megfogalmazásában „a szabadidő, mint időkeret a munkán kívüli időnek az a része, amely anyagi, tehát gazdasági, társadalmi, fiziológiai - kényszer alapján feltétlenül szükséges elfoglaltságok idején felül, e kényszeresen kívül eső tevékenységekre fennmarad."16

Falussy Béla gondolatait Kovács Tamás Attila az alábbiak szerint összegzi: „a társadalmi összidőt tekintve az emberi tevékenységeket 3 típusba sorolva határozza meg a szabadidő fogalmát. Első helyen elkülöníti azokat a cselekményeket, amelyeket, mint társadalmi lény, tehát - az egyén és a többiek viszonylatában - végzünk, második csoportba sorolja mindazon tevékenységeket, amellyel önmagunkat látjuk el, tartjuk fönn (én-magamat). A fennmaradó idő kerül a szabadidő »puttonyába «". ${ }^{7}$

Az irányadó szakirodalom e fogalomhoz kötődően különbséget tesz free time és leisure (time) kifejezések között is. Alapvetően több közép-európai országban használják

12 Vö.: Fritz Péter: Mozgásos rekreáció, Bába Kiadó, Szeged, 2011, 15-19.;

Fritz Péter et al.: Kapcsolat az életmód, szabadidő és rekreáció között, Magyar Sporttudományi Szemle, 8 (2007/2) 52-56. http://mstt.hu/MSSZ/MSTT_200702.pdf (Letöltve: 2017. 11. 13)

13 Fritz (2011): i. m. 16.

14 Fritz Péter: Szellemi rekreáció, Dialóg Campus Kiadó, Budapest-Pécs, 2015, 23.

15 Fritz (2015): i. m. 24.

Fritz (2011): i. m. 16.

17 Kovács Tamás Attila: A rekreáció kultúrája, A rekreáció főbb kulturális alrendszerei, Magyar Sporttudományi Szemle, (2007/2) 15. http://mstt.hu/MSSZ/MSTT_200702.pdf (Letöltve: 2017. 11. 13) 
mind a két fogalmat a szabadidő - Freizeit - értelmében. Fontos megjegyezni azonban, hogy míg a "szabadidő" elsősorban az időgazdálkodásban és a tevékenységválasztásban megvalósítható szabadságot jelöli, addig a „leisure" szempontjából lényeges egy sajátos szellemi/tudatállapot (flow?), amely sokban hasonlít a görög „skol”, a latin opium, a német „Muße” vagy a francia „loisir" fogalmakra. ${ }^{18}$ Összességében, Fritz szavaival élve „a »free time« tehát a nem munkával töltött idő, míg a »leisure« a minőségi szabadidő, vagy más szóval rekreáció."19

Amennyiben statisztikai értelemben szeretnénk a szabadidőt megközelíteni, akkor az időmérleg-statisztika tud tájékoztatást adni arról, hogy hogyan alakul az újratermelése társadalmi és gazdasági alapjainak, valamint a társadalom időalapjának. Összességében arról kaphatunk információkat, hogy hogyan is alakul az embereknek a napi-, heti, illetve teljes idejének a felhasználása. ${ }^{20}$

Ezen a területen a Központi Statisztikai Hivatal (a továbbiakban: KSH) az, aki rendszeres időközönként készít úgynevezett időmérleg-vizsgálatot.

Falussy Béla szavaival élve „az időmérleg az életmód, mint hierarchikus rendszerbe szervezett tevékenységstruktúra felmérésére, egyben az egyes tevékenységek vizsgálatára kialakított társadalomstatisztikai adatfelvételi és elemző eljárások összessége, ugyanakkor ezek elrendezésével, a társadalom időfelhasználásáról nyert adatok, társadalmi jelzőszámok rendszerébe is besorolható."21 (A KSH az 1960-as évek óta, nagyjából 10 évente hajt végre Magyarországon ilyen adatfelvételt. ${ }^{22}$ ) A felmérés a rendelkezésre álló időt a nemzetközi osztályozásnak megfelelően alapvetően három fő blokkra osztja:23

- társadalmilag kötött tevékenységek köre; ${ }^{24}$

- fiziológiailag kötött tevékenységek köre; ${ }^{25}$

- szabadon végezhetö tevékenységek köre. ${ }^{26}$

A fenti tevékenységi csoportok alapján a $\mathrm{KSH}$ rendszerében a szabadon végezhető tevékenységek köre ${ }^{27}$ az, amely lényegében a szabadidőt az általa meghatározott tevékenységi körökkel lefedi.

\footnotetext{
Kovács (2007): i. m.

Fritz (2015): i. m. 26.

Gyémánt Richárd: Társadalomstatisztika, Pólay Elemér Alapítvány - Szegedi Egyetemi Kiadó, Szeged, 2007, 119-122.

21 Falussy Béla: Tevékenységosztályozási rendszerek az időmérleg-vizsgálatokban, Statisztikai Szemle, 85 (2007/8) 691. www.ksh.hu/statszemle_archive/2007/2007_08/2007_08_690.pdf (Letöltve: 2017. 11. 14.)

22 A legutóbbi adatfelvételre, a tanulmány írásakor, a magánháztartásokban 2009. október 1. és 2010. szeptember 30. között került sor a 10-84 éves népesség körében.

23 Vö.: Klinger András: Társadalomstatisztikai alapismeretek, KSH, Budapest, 1998, 56-57.

24 Ide azok a tevékenységek sorolhatók be, amelyek végzésére vagy nem végzésére nincs választás. Például jövedelemszerző tevékenység, tanulás, közlekedés stb. Falussy (2007): i. m.

25 Ebbe a blokkba a fizikai regenerációt szolgáló tevékenységek tartoznak. Ugyancsak kötött tevékenységekről van szó, amelyeket többnyire ugyancsak napi rendszerességgel végeznek; alvás, étkezés stb. Falussy (2007): i. m.

26 Minden olyan tevékenység kapcsolódik ide, amely az első két blokkból kimaradt. Ezeket a tevékenységeket egyénileg, szabad akarattal lehet megválasztani. Ez az az időkeret, amely a szellemi, lelki, fizikai rekreációt, feltöltődést szolgálja, például olvasás, testedzés, tévénézés stb. Falussy (2007): i. m.

27 Vö.: Időmérleg 2009/2010 Összefoglaló adattár, Központi Statisztikai Hivatal, Budapest, 2012, 177-180.
} 
A KSH 10 évvel ezelőtti felmérésének adatai szerint ${ }^{28}$ (1. táblázat) a „15-74 éves népesség rendelkezésre álló napi idejének kb. a felét fiziológiai szükségleteinek kielégítésére fordította, egyharmadát a társadalmilag kötött tevékenységek tették ki, a szabadon végzett tevékenységekre pedig mindössze annak egyötöde jutott." ${ }^{29}$

A három tevékenységi körből az első és a harmadik csoportba tartozó tevékenységek egymáshoz viszonyított aránya az, amely hosszabb távon, lassan, de jelentős változást elérve tud átalakulni. ${ }^{30}$

1. táblázat: 15-74 éves korosztály napi átlagos időráforditása, nemek szerint együtt, perc/fö („A" mutató)

\begin{tabular}{|c|c|c|c|}
\hline \multicolumn{5}{|c|}{ 15-74 éves korosztály napi idöráforditása, nemek szerint együtt, perc/fö („A" mutató) } \\
\hline Tevékenységek & $1986 / 1987$ & $1999 / 2000$ & $2009 / 2010$ \\
\hline $\begin{array}{c}\text { Társadalmilag kötött } \\
\text { tevékenységek }\end{array}$ & 540 & 478 & 461 \\
\hline $\begin{array}{c}\text { Fiziológiailag kötött } \\
\text { tevékenységek }\end{array}$ & 671 & 683 & 713 \\
\hline $\begin{array}{c}\text { Szabadon végzett } \\
\text { tevékenységek }\end{array}$ & 230 & 280 & 266 \\
\hline
\end{tabular}

Forrás: Időmérleg 2009/2010, Összefoglaló adattár, Központi Statisztikai Hivatal, Budapest 2012, 107. adatai alapján a szerző szerkesztése

A 2010-es felmérés során, a 15-74 éves népesség kevesebb, mint 8 órát fordított a társadalmilag kötött tevékenységi körökre, szemben az 1970-es években mért 9 és fél órával, és ezzel párhuzamosan pedig nőtt a szabadon felhasználható időkeret is. Ugyanakkor Bárdosi Mónika és Tabajdi Márta is kitér arra is, hogy a szabadidő mértéke szoros összefüggésben áll például az egyén társadalmi munkamegosztásban betöltött szerepével; ki milyen életszakaszban, illetve milyen élethelyzetben van, vagy hogy férfiről vagy nőről van-e szó. ${ }^{31}$

A 2010-es adatokból az is egyértelműen megállapítható, hogy a 15-74 éves népesség naponta átlagosan közel 4 és fél óra szabadidővel rendelkezett. Nem szabad azonban megfeledkezni arról, hogy ez az érték (2. táblázat) inkább a még tanuló, illetve a nyugdíjasokból álló korosztályokra vonatkoztatható. Ók azok, akik a legtöbb időt tudják fordítani a szabadidősnek tekintett foglalatosságokra, míg a jellemzően aktív korosztály tagjai, vagyis azok, akik dolgoznak, gyermeket nevelnek, háztartást látnak el, rendelkeznek a legkevesebb szabadidővel. ${ }^{32}$

28 A KSH 2018. 10. 25-én kelt sajtóhíre alapján a 2020-as adatfelvétel előkészületei jelen tanulmány írásakor folyamatban voltak. Az időmérleg rendszer legújabb adatai, eredményei ezt követően várhatók. Sajtóhír forrása: www.ksh.hu/sajtoszoba_kozlemenyek_tajekoztatok_2018_10_25 (Letöltve: 2019.11. 10.)

29 Bárdosi Mónika - Tabajdi Márta: Kulturálódási szokásaink, Központi Statisztikai Hivatal, Budapest, 2013, 6.

30 Bárdosi-Tabajdi (2013): i. m.

31 Bárdosi-Tabajdi (2013): i. m.

32 Fekete Mariann: Generációs szabadidő-felhasználás képernyőn innen és képernyőn túl az 1999/2000-es és a 2009/2010-es időmérleg-vizsgálat tükrében, Kötő - jelek 2014, 133-159. https://tatk.elte.hu/dstore/document/112/koto_jelek_2014. pdf (Letöltve: 2017. 11. 13.) 
2. táblázat: 15-74 éves korosztály napi átlagos időráforditása, nemek szerint együtt, perc/fö („A” mutató)

\begin{tabular}{|c|c|c|c|c|c|c|}
\hline & \multicolumn{6}{|c|}{ 15-74 éves korosztály napi idöráforditása, nemek szerint együtt, perc/fö („A" mutató) } \\
\cline { 2 - 7 } Korcsoport & $\begin{array}{c}15-19 \\
\text { éves }\end{array}$ & $\begin{array}{c}20-29 \\
\text { éves }\end{array}$ & $\begin{array}{c}30-39 \\
\text { éves }\end{array}$ & $\begin{array}{c}40-49 \\
\text { éves }\end{array}$ & $\begin{array}{c}50-59 \\
\text { éves }\end{array}$ & $\begin{array}{c}60-69 \\
\text { éves }\end{array}$ \\
\hline $\begin{array}{c}\text { Szabadon } \\
\text { végzett } \\
\text { tevékenység }\end{array}$ & 311 & 274 & 220 & 225 & 266 & 331 \\
\hline
\end{tabular}

Forrás: Időmérleg 2009/2010, Összefoglaló adattár, Központi Statisztikai Hivatal, Budapest 2012, 122., 125., 128., 131., 134., 137. oldal adatai alapján a szerző szerkesztése

Amennyiben a napi átlagos időráfordítást is megvizsgáljuk a 15-74 éves népesség körében, azt tapasztalhatjuk, hogy kiugróan magas értéket képvisel a "Tévénézés, rádiózás, internetezés". Sőt, egyértelmúen megállapítható, hogy ez a legjellemzőbb kulturális időtöltés, hiszen a 2010-es adatfelvétel során, az adatfelvételre kijelölt napon a megkérdezettek 87,4\%-a válaszolta, hogy a rendelkezésére álló szabadidőt képernyő előtt töltötte.

3. táblázat: A 15-74 éves népesség napi időfelhasználása nemek szerint együtt

\begin{tabular}{|c|c|c|}
\hline & \multicolumn{2}{|c|}{ 15-74 éves korosztály napi időráforditása, nemek szerint együtt } \\
\hline & $\begin{array}{c}\text { A tevékenységet végzők aránya } \\
\text { \%-ban („B" mutató) }\end{array}$ & $\begin{array}{l}\text { A tevékenységet végzők időráfordí- } \\
\text { tása perc/fő („C" mutató) }\end{array}$ \\
\hline & \multicolumn{2}{|c|}{$2009 / 2010$} \\
\hline $\begin{array}{l}\text { Szabadon végzett } \\
\text { tevékenységek }\end{array}$ & 97,7 & 272 \\
\hline Szabadidő társas eltöltése & 54,4 & 88 \\
\hline Vallásgyakorlás & 2,2 & 76 \\
\hline Mozilátogatás & 0,8 & 126 \\
\hline $\begin{array}{c}\text { Egyéb kulturális intézmények } \\
\text { látogatása }\end{array}$ & 0,8 & 141 \\
\hline Olvasás & 25,9 & 76 \\
\hline ebből: könyv olvasása & 7,7 & 97 \\
\hline Rádió hallgatása & 1,6 & 64 \\
\hline $\begin{array}{l}\text { Tévénézés, videózás, } \\
\text { internetezés }\end{array}$ & 87,4 & 174 \\
\hline $\begin{array}{l}\text { Séta, kirándulás, } \\
\text { sport, testedzés }\end{array}$ & 15,3 & 96 \\
\hline ebből: sport, testedzés & 6,7 & 85 \\
\hline $\begin{array}{c}\text { Hobbi jellegű tevékenység, } \\
\text { növények, házi kedvencek } \\
\text { gondozása }\end{array}$ & 19 & 53 \\
\hline $\begin{array}{l}\text { ebböl: szobanövények, házi } \\
\text { kedvencek gondozása }\end{array}$ & 15,9 & 40 \\
\hline
\end{tabular}

Forrás: Időmérleg 2009/2010, Összefoglaló adattár, Központi Statisztikai Hivatal, Budapest 2012, 108-109. adatai alapján a szerző szerkesztése 
Ugyanakkor kedvezőbb értéket figyelhetünk meg, ha a 15-74 éves népesség napi időfelhasználásakor azt vizsgáljuk, hogy a megfigyelt sokaságnak hány százaléka, milyen időráfordítással végzett „séta, kirándulás, sport, testedzés” tevékenységet, és ebböl mennyi volt a kifejezetten „sport, testedzés”. Itt a megkérdezettek 15,3\%-a kicsivel több mint másfél órát fordított az előbbi tevékenységi körre, és ebböl kifejezetten sportra és testedzésre, a megkérdezettek 6,7\%-a szánt kicsivel kevesebb, mint másfél órát (3. táblázat).

Továbbá, ha a napi átlagos időráfordításra vonatkozó adatokat megvizsgáljuk a 15-74 éves népesség napi átlagos időráfordítása alapján, akkor a vizsgált értékekre vonatkozó adatok szinte elhanyagolható időráfordítást mutatnak. Ez a tény pedig azért is problematikus, mivel a rendszeres testmozgás egészségre gyakorolt pozitív hatásáról már számtalan tudományos cikk, elemzés, tanulmány stb. látott napvilágot. Ennek ellenére, a szabadidőfelhasználási adatokból egyértelmü következtetésként vonható le, hogy e munkák elméleti eredményei nem tükröződnek a mindennapok gyakorlatában.

Léteznek természetesen más módszerek, felmérések is a szabadidő vizsgálatára, amelyek bár részeiben, s így egyszersmind eredményeiben is eltérnek egymástól, egy pontban azonban sajnos azonos következtetést adnak: a megkérdezettek szabadidejének jelentős részét egyértelműen a tévénézés alkotja, és a fennmaradó, jellemzően kisebb időtartamú időbe tartozik az összes többi szabadidőben végezhető tevékenység. ${ }^{33}$

A fizikai aktivitás-inaktivitás kérdése nemcsak egészségünk megőrzésében játszik kardinális szerepet, hanem jelentős gazdasági vetülettel is rendelkezik. Ebben a kérdésben Ács és szerzőtársai 2011-es tanulmányukban nem kevesebbre vállalkoztak, mint hogy az Eurobarometer 2005-ös és 2010-es felmérésének, az OEP 2010-es, a KSH adatainak, valamint egy saját országos lefedettségű nagymintás kérdőives kutatásuk adatai alapján számszerüsítsék a (1) a betegségek gazdasági terheit, (2) a fizikai inaktivitás költségeit, valamint (3) a fizikai aktivitás növelésével elérhető éves megtakarítások elméleti volumenét.

A szerzők ebben a munkájukban többek közt megállapították, hogy 2009-ben az inaktivitással összefüggésben lévő betegségek és azok szövődményei, az államnak 283,5 milliárd forint költséget jelentettek. Kutatásuk arra az eredményre jutott, hogy, ha a lakosság $77 \%$-os inaktivitási szintjét csupán 10\% ponttal lehetne csökkenteni, akkor ez 2009-ben, nemzetgazdasági szinten évente 9,1 milliárd forint, míg a táppénzek terén 1,8 milliárd forint megtakarítást eredményezett volna. ${ }^{34}$

Stocker Miklós és Ács Pongrác egy 2012-es tanulmánya további tartalmas adatokkal bővíti a megtakarítás mértékének részletezését. Eszerint, „ha az egészséget pénzügyi befektetésként kezelnénk, akkor a magyar államnak 545 milliárd forintot érne a 10\%-os aktivitásnövelés, amely esetében a lakosság további 170 milliárd forintot, a munkáltatók pedig 107 milliárd forintot realizálnának. Másik szemszögből gazdaságilag 17 ezer

33 Tibori Tímea: Kulturális magatartás- és értékváltozások, Educatio, 10 (2001/3) 517-529. http://folyoiratok.ofi.hu/sites/ default/files/article_attachments/tibor_t_2001_03.pdf (Letöltve: 2017. 11. 15.)

34 Ács Pongrác - Hécz Roland - Paár Dávid - Stocker Miklós: A fittség (m)értéke, Közgazdasági Szemle, 58 (2011/júliusaugusztus) 689-708. http://unipub.lib.uni-corvinus.hu/440/1/Kszemle_CIKK_1259.pdf (Letöltve: 2017. 09. 20.) 
forintot érne minden lakosnak, ha a fizikai aktivitást 10\%-kal tudnánk növelni, míg ehhez 54 ezer forintot adhatna az állam és 10 ezer forintot a munkáltató."35

Különösen fontos lehet ennek a kérdésnek a vizsgálata a honvédelem terén is, ahol a fentieken túl azzal is számolni, kell, hogy azoknál a szervezeteknél, „ahol a munkaerő speciális kiképzése hosszú időt, éveket vesz igénybe és viszonylag magas költséggel jár (pl. a repülő-hajózó állomány), a humán erőforrás értéke relatíve magasabb, ezáltal az egészséget támogató intézkedések megléte megkérdőjelezhetetlen. A munkaképesség megtartására, az egészségi állapot fenntartására fordított pénzösszegek jól megtérülő befektetésként értelmezhetőek, mivel a gyógyító ellátás költségéhez viszonyítva a prevenció költséghatékonysága az aktív, munkaképes korosztályra fordítva 5-10-szer magasabb."36

A fentiek alapján megállapítható, hogy a szabadidő minél tartalmasabb, fizikailag és szellemileg is aktív felhasználása nemcsak egyéni, de igen komoly gazdasági érdek is. Ugyanakkor az irányadó időfelhasználási adatok egyértelműen azt mutatják, hogy a lakosság ezt az időkeretet inkább passzív módon tölti el. Éppen ezért felvetődik a kérdés, hogy vajon lehet-e és ha igen, akkor hogyan lehet ezt a kiesett időt pótolni? Vajon az egészségfejlesztő jellegű és célzatú fizikai aktivitást csak a rendelkezésünkre álló szabadidő terhére lehetne eltölteni, vagy megjelenhet-e esetleg más területen is?

\section{Munkahelyi egészségfejlesztés}

Életünk jelentős és egyszersmind legtermékenyebb időtartamát a munkahelyünkön, főfoglalkozásunk végzésével töltjük. A már korábban hivatkozott időmérleg eredményeit kiegészíti egy másik, hazai munkapszichológusok (Gordio-csoport) által vezetett vizsgálat eredménye is, amelyből kiderült, hogy „egy magyar munkavállaló heti munkahete 44,5 ledolgozott óra, amely mintegy napi 1 órával hosszabb az elöírt 8 óránál." ${ }^{37}$ Életünknek a harmadát - ami egyes számítások szerint több mint 80 ezer órát jelent - az időmérleg rendszerében az úgynevezett társadalmilag kötött tevékenységi kör végzésére fordítjuk. ${ }^{38} \mathrm{Nem}$ mindegy tehát, hogy milyen körülmények között töltjük el ezt az időtartamot.

Bajsz és szerzőtársai 2013-as értekezésükben kitértek arra, hogy az elmúlt több évtized kutatási eredményei már egyértelmüen igazolták azt a tézist, hogy a rossz munkahelyi körülmények növelik a munkahelyi stresszt, amelynek így közvetlen hatása van munkavállalók testi és lelki egészségére. Ez pedig nemcsak a munkavállalók egészségére hat károsan, de ezzel párhuzamosan csökkenti a szervezet hatékonyságát, és végső soron gazdasági károkat is okoz az érintett vállalatnak/szervezetnek. ${ }^{39}$

35 Stocker Miklós - Ács Pongrác: A sportolás növelésével elérhető gazdasági haszon mértéke, Magyar Sporttudományi Szemle, 13 (2012/3) 25. http://mstt.hu/MSSZ/MSSZ_201203.pdf (Letöltve: 2017. 11. 15.)

36 Sótér (2017): i. m. 23.

37 Gábor Edina - Kiss Judit: Munkahelyi egészségfejlesztés - a minőség jegyében I., Egészségfejlesztés, 50 (2009/4) 2. http:// folyoirat.nefi.hu/index.php?journal=Egeszsegfejlesztes\&page=article\&op=view\&path\%5B\%5D=112 (Letöltve: 2017.09. 20.)

38 Gábor-Kiss (2009): i. m.

39 Bajsz Viktória et al.: Egy multinacionális cég egészségfelmérése a munkahelyi stressz tükrében, Egészségfejlesztés, $54(2013 / 5-6)$ 40-47. 
Az egészség ennek megfelelően nemcsak a munkavállalónak, hanem a munkáltatónak is igen komoly érték lehet. Ács és szerzőtársai értekezése azzal, hogy megbecsülte a fizikai inaktivitás csökkenésével elérhető megtakarítások számszerüsíthető mértékét, lényegében kiindulási alapot is adott arra vonatkozóan, hogy a munkáltatók számára ezenfelül milyen további előnnyel jár, ha nagyobb figyelmet fordítanak munkavállalóik egészségére. A megtakarításon túl ugyanis nemcsak hogy nem kell a betegség miatt hosszabb-rövidebb időre, vagy netán a kiégettség vagy motiváció hiánya miatt végleg kiesett munkavállalót pótolniuk, hanem akár egyszerre képesek komoly előnyt is szerezni a versenytársaikkal szemben. Így pedig képesek lesznek tovább erősíteni a piaci helyzetüket csupán azzal, hogy a munkavállalók mentálisan és fizikailag is egészségesek, motiváltak, valamint egészségmegtartásuk protektív (védelmező) és prediktív (elörejelző) tényezőinek ismereteivel is rendelkeznek. ${ }^{40}$

A munkahelyen történő egészségfejlesztés mindenki számára hasznos és kifizetődő tevékenység lehet. Fontos azonban kitérni arra, hogy „a munkahelyi egészségfejlesztés nem ellentéte, kiváltója a hagyományos munkavédelemnek, hanem kiegészíti azt, bővíti az egészséges munkahely/munkavilág megvalósításának lehetőségeit". ${ }^{41}$

A Munkahelyi Egészségfejlesztés Európai Hálózatának 1997-ben elfogadott Luxemburgi Deklarációjának értelmében: „a munkahelyi egészségfejlesztés a munkaadók, a munkavállalók és a társadalom valamennyi olyan közös tevékenységét jelenti, amely a munkahelyi egészég és jól lét javítására irányul. A cél eléréséhez három eszközrendszer együttes alkalmazása szükséges: a munkaszervezet javítása, az aktív dolgozói részvétel biztosítása és támogatása, valamint az egyéni kompetencia erősítése."142

Ez az eljárás tehát nemcsak arra irányul, hogy feltárják és kiküszöböljék azokat a potenciális veszélyforrásokat, amelyek a munkavállalókat munkavégzésük során fenyegethetik, meggátolva ezzel az esetleges egészségromlást és betegség kialakulását, hanem megpróbálja a munkavállalókat aktív részesévé tenni önmaguk egészségi állapotának alakítására. Ehhez igyekszik minél több eszközt, lehetőséget, segítséget biztosítani. ${ }^{43}$

A munkahelyi egyészségfejlesztés eszköze az egészség, célja pedig a munkavégzőképesség helyreállítása és növelése, illetve a mihamarabbi, gyors regeneráció elérése. ${ }^{44} \mathrm{~A}$ hon- és rendvédelmi szervek esetében azért is kiemelten fontos ez a kérdés, mivel „[a] 25 év szolgálat utáni, szolgálati nyugdíjba vonulás lehetőségének megszűnésével az idősebb, 50 év felettiek létszáma emelkedik az állomány körében. Az idősebb korral együtt járó egészségi problémák a fokozott terhelés miatt hatványozottan jelentkeznek, amely egyrészt speciális ellátási igényt támaszt az egészségügyi ellátórendszerrel szemben, másrészt a megbetegedés miatt szolgálatból kiesett munkavállaló

40 Nagyváradi Katalin - Kiss-Geosits Beatrix: A munkahely, mint az egészségfejlesztés multiplikációs színtere, Egészségfejlesztés, 52 (2011/3) 14-16.

41 Galgóczy Gábor: A munkahelyi egészségfejlesztés európai gyakorlata (Bemutatkozik a Munkahelyi Egészségfejlesztés Európai Hálózata), in: Kapás Zsolt (szerk.), Egészséges munkavállaló az egészséges munkahelyeken, A munkahelyi egészségfejlesztés jelene és jövője, Országos Egészségfejlesztési Intézet, Budapest, 2004, 7.

42 Galgóczy (2004): i. m. 8-9.

43 Fritz Péter et al.: A munkahelyi egészségfejlesztés európai gyakorlata, Budapesti Népegészségügy, 35 (2004/4) 324-330

44 Fritz Péter: A rekreáció fogalma, rendszertani felosztása, in: Fritz Péter (szerk.), Alapfogalmak és jelentéseik a rekreació területén: Rekreáció mindenkinek III., Miskolci Egyetemi Kiadó, Miskolc, 2019, 25. 
helyettesítése humánerőforrás gazdálkodási problémaként is jelentkezik". 45 Emiatt is igen lényeges Dr. Böröndi Gábor altábornagy, a Magyar Honvédség parancsnoksága helyettesének az a honvédelem keretében történő egészségfejlesztési programokkal összefüggésben tett kijelentése, miszerint: „[a] Honvédelmi és Haderőfejlesztési Program középpontjában az ember, a katona áll. Rá kell bírnunk a hivatásos és szerződéses állományt, a honvédelmi alkalmazottakat, hogy éljenek a lehetőséggel és sportoljanak, egészséges élelmezésen alapuló receptúrát kell rendszeresítenünk a Magyar Honvédségben, és azokat a kognitív idegrendszert támogató programokat is be kell vezetnünk, amelyek fitté teszik a katonát, képessé arra, hogy valóban digitális katonává váljon." ${ }^{146}$

Mivel már igazolást nyert, „hogy a munkáltató akkor szolgálja a rekreáció megvalósulását, ha a munkavállalóknak - betartva a munkaszerződésben meghatározott munkaidőt - szabadidőt, a szabadidejükben a rekreációs tevékenységekhez feltételés eszközrendszert vagy különböző támogatási formát biztosít. A kötelező jelleggel bevezetett egészéget célzó tevékenységek bizonyítják, hogy a munkavégző képesség helyreállításával a rekreáción kivül más tevékenységek is foglalkoznak."147 Ennek okán pedig bevezették a rekreációs többlet fogalmát, amely nem mást, mint „a nem szabadidős tevékenységekben keletkező rekreációs hatásokat jelenti". ${ }^{48}$ Ez a többlet pedig bármely tevékenységi csoportban megjelenhet: úgy a fiziológiai szükségletek körében, mint főzés, bevásárlás, vagy éppen a munkahelyünkön, ha az ottani feladatokat jó kedvvel végezzük. ${ }^{49}$

\section{Munkahelyi egészségfejlesztés az európai gyakorlatban (Fritz és szerzőtársainak 2004-es munkája alapján) ${ }^{50}$}

Fritz és szerzőtársainak 2004-es tanulmánya olyan részletes összehasonlító elemzést mutat be, amelyben 19 európai ország 66 vállalatának egészségfejlesztési módszereit és eredményeit vizsgálták meg. A kutatás legfontosabb eredményei közé tartozik, hogy a szerzők kiválasztották a 7 leggyakrabban alkalmazott mérőszámtípust (1. ábra), és a 66 vizsgált társaságnál megvizsgálták alkalmazásuk százalékos eloszlását. Ennek alapján a kutatók arra a megállapitásra jutottak, hogy a 7 kategória valamennyi értéke minden esetben pozitív irányú elmozdulást mutatott, vagyis:

- Csökkent a betegség miatti hiányzások száma,

- Javult a munkahelyi légkör;

- Csökkent a munkahelyi balesetek száma;

- Nőtt a munkavállalóval való megelégedettség és motiváltság;

5 Sótér (2017): 22.

46 Antal Ferenc: Egészségfejlesztés a Magyar Honvédségben. https://honvedelem.hu/cikk/egeszsegfejlesztes-a-magyarhonvedsegben/ (2020. 03. 27.)

47 Fritz (2018): i. m. 25.

48 Fritz (2018): i. m. 25

49 Fritz (2018): i. m. 25.

50 Fritz et al. (2004): i. m. 
- Növekedtek a munkafeltételek és a munkahelyi biztonság;

- Csökkent a személyzeti állomány cseréje;

- Pozitív hatást gyakorolt a termelékenységre és a társaság imázsára.

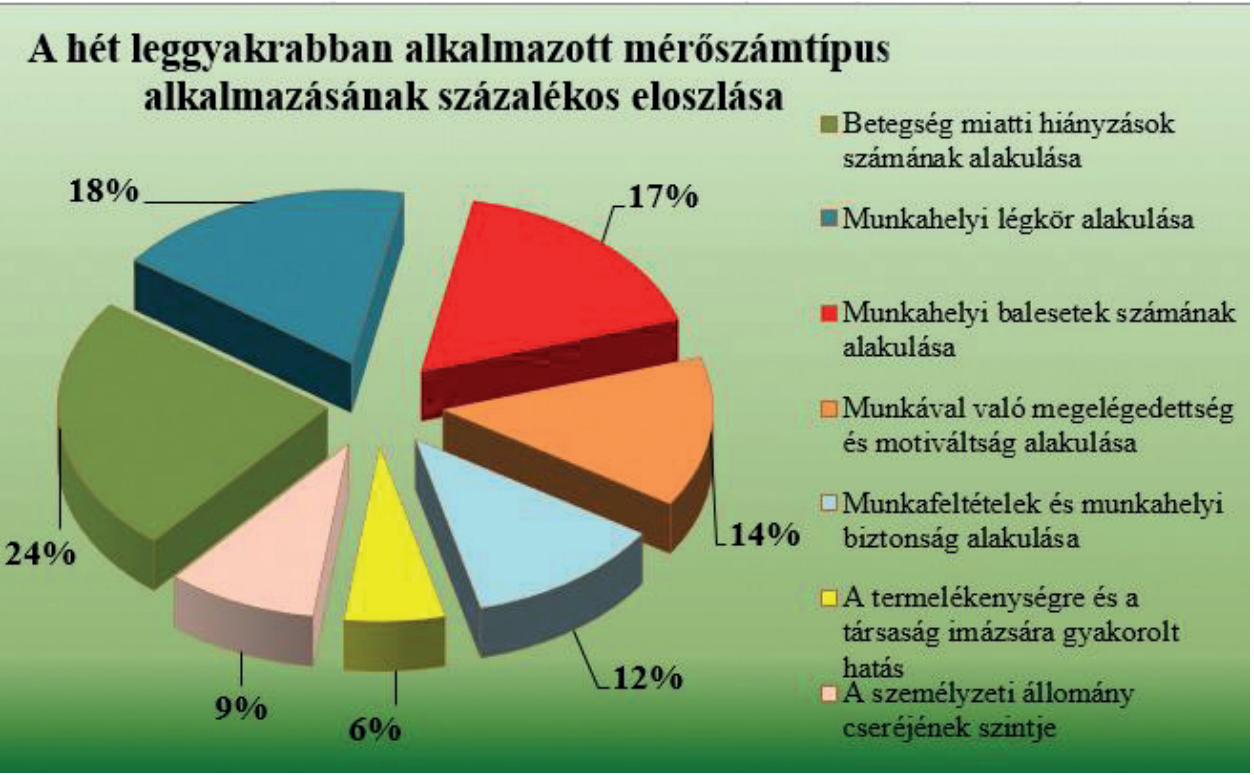

1. ábra: A hét leggyakrabban alkalmazott méröszámtípus alkalmazásának százalékos eloszlása

A szerzők a hatékonysági vizsgálat miatt elkülönítik a fenti típusokat, ugyanakkor megállapítják, hogy „szoros kapcsolatban és ok-okozati viszonyban állnak egymással. Például, ha a munkafeltételek javulnak és a munkahelyi biztonság növekszik, akkor a munkahelyi balesetek száma csökken, így a betegség miatti hiányzások száma is csökken. Ez javítja a munkahelyi légkört és összességében jótékony hatást gyakorol a termelékenységre." ${ }^{11}$

Álláspontom szerint a fenti kutatás eredménye teljes mértékben alkalmas arra, hogy objektív, tárgyilagos eredményeket adjon egy jól összeállított, átgondolt, hozzáértő szakértőkkel rendelkező egészségfejlesztési program hatékonyságáról, ezen túlmenően, miként a tanulmány szerzői is kiemelik, segítséget tud nyújtani egy hasonló program megtervezéséhez, illetve bevezetéséhez is. 


\section{Civil szféra}

Hazánkban, a rendszerváltozást követö években végbemenő politikai, gazdasági és társadalmi átalakulás egyértelműen pozitív hatással bírt a civil szféra fejlődésére. A korábbi akadályok megszünésével, valamint azzal, hogy az előző időszak gyakorlatától eltérően, az állam fokozatosan visszavonult több, általa korábban támogatott társadalmi kérdést érintő terület támogatásától, nemcsak hogy igény merült fel, de fokozottabb szükségletként meg is jelent a társadalmi önszerveződések létrejötte és működése. A nonprofit szektor fejlődésének egyik legfontosabb oka tehát az volt, hogy a megváltozott rendszerrel olyan új társadalmi igények jelentek meg, amelyeket sem az állam, sem pedig a piaci szektor nem tudott biztosítani. ${ }^{52}$

A KSH a civil szervezetek működését 1993 óta az alábbi három mutatóval figyeli: (1) müködő szervezetek száma; (2) bevételek reálértéke; (3) foglalkoztatottak száma. Ezekből a mutatókból egyértelműen megállapítható, hogy 2008-ig erős fejlődési tendencia volt tapasztalható, majd a válság hatására ez az ütem mérséklődött, és végül, 2012-ben először fordult elő, hogy ezek a görbék az előző évek mutatóihoz képest lefelé mozdultak el. A szervezetek száma azóta is fokozatosan csökken, bár ez a hatás már az új civil törvény ${ }^{53}$ által bevezetett rendelkezéseknek volt inkább betudható, amelyek egyfajta tisztulási folyamatot indítottak el a szektoron belül. ${ }^{54}$

Az új civil törvény egyik jelentős, új rendelkezése a civil szervezeteket érintő közhasznú jogi státusz szabályozását érintette. A 2012. január 1-jén hatályba lépő új szabályozás ${ }^{55}$ eredményeként „2015 év végi bírósági adatok szerint a bejegyzett szervezetek alig több mint 20\%-a rendelkezett közhasznú minősítéssel, szemben a 2013. évi „kifutó évben” mért 55\%-kal”. 56

A 2011-ben elfogadott új szabályozás másik nagy újítása az volt, hogy a magyar jogrendszerbe új gyüjtőfogalomként bevezette a „civil szervezet” fogalmát. „E fogalmi kategória a civil társaságot, az egyesületet - a párt, szakszervezet és kölcsönös biztosítópénztár kivételével - valamint az alapítványt - a közalapítvány és a pártalapítvány kivételével - öleli fel." 57

Ahogyan arra Kaprinay Zsófia a változásokra irányadó értekezésében kitér, a „Központi Statisztikai Hivatal a nonprofit szektoron belül elkülöníti a »klasszikus civil szervezeteket«, melyet a nonprofit szektor »alszektorának« nevez. Ennek indoka az, hogy határozott igény mutatkozik arra, hogy ezt a szektort a teljes nonprofit szektortól elkülönítsék; idesorolja a magánalapítványokat, valamint az egyesületeket.

2 Bucher (2012): i. m.

53 2011. december 5-én fogadták el az egyesülési jogról, a közhasznú jogállásról, valamint a civil szervezetek müködéséről és támogatásáról szóló 2011. évi CLXXV. törvényt, vagyis az új civil törvényt.

54 Statisztikai Tükör: A nonprofit szektor legfontosabb jellemzői, 2015, Budapest, Központi Statisztikai Hivatal, 2016, www. ksh.hu/docs/hun/xftp/stattukor/nonprofit/nonprofit15.pdf (Letöltve: 2017. 09. 20.)

55 2011. évi CLXXV. törvény az egyesülési jogról, a közhasznú jogállásról, valamint a civil szervezetek müködéséröl és támogatásáról, VII. fejezet.

56 Statisztikai Tükör: A nonprofit szektor legfontosabb jellemzői, 2015, Budapest, Központi Statisztikai Hivatal, $2016,2$. www.ksh.hu/docs/hun/xftp/stattukor/nonprofit/nonprofit15.pdf (Letöltve: 2017. 09. 20.)

57 Kaprinay Zsófia: A civil szervezet, mint új fogalmi kategória, és annak lehetséges megközelítései, Miskolci Jogi Szemle, 10 (2015/1) 94. www.mjsz.uni-miskolc.hu/201501/8_kaprinayzsofia.pdf (Letöltve: 2017. 11. 13.) 
A teljes nonprofit szférában nyolc szervezet közül hét szervezet ebbe a klasszikus civil szektorba tartozik, tehát a nonprofit szektor legnagyobb részét teszik ki" (2. ábra). ${ }^{58}$

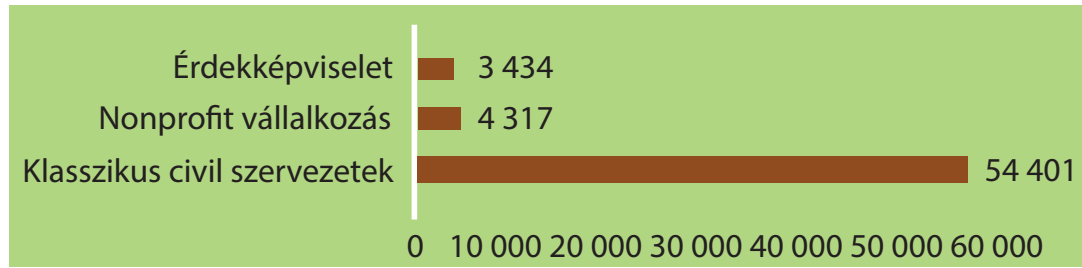

2. ábra: A nonprofit szervezetek száma szervezeti forma szerint, 2015

Forrás: Nonprofit szervezetek Magyarországon,2015, Adattár, Budapest 2017, 1.4-es táblázat adatai alapján a szerző szerkesztése

A KSH besorolása alapján a klasszikus civil szervezet körébe, ahogyan Kaprinay munkásságából is egyértelmüen megállapítható, az alapítványok és az egyesületek tartoznak, arról pedig, hogy ezek a szerveződések miként csoportosíthatók a tevékenységi körük szerint, a 3. ábra nyújt segítséget.

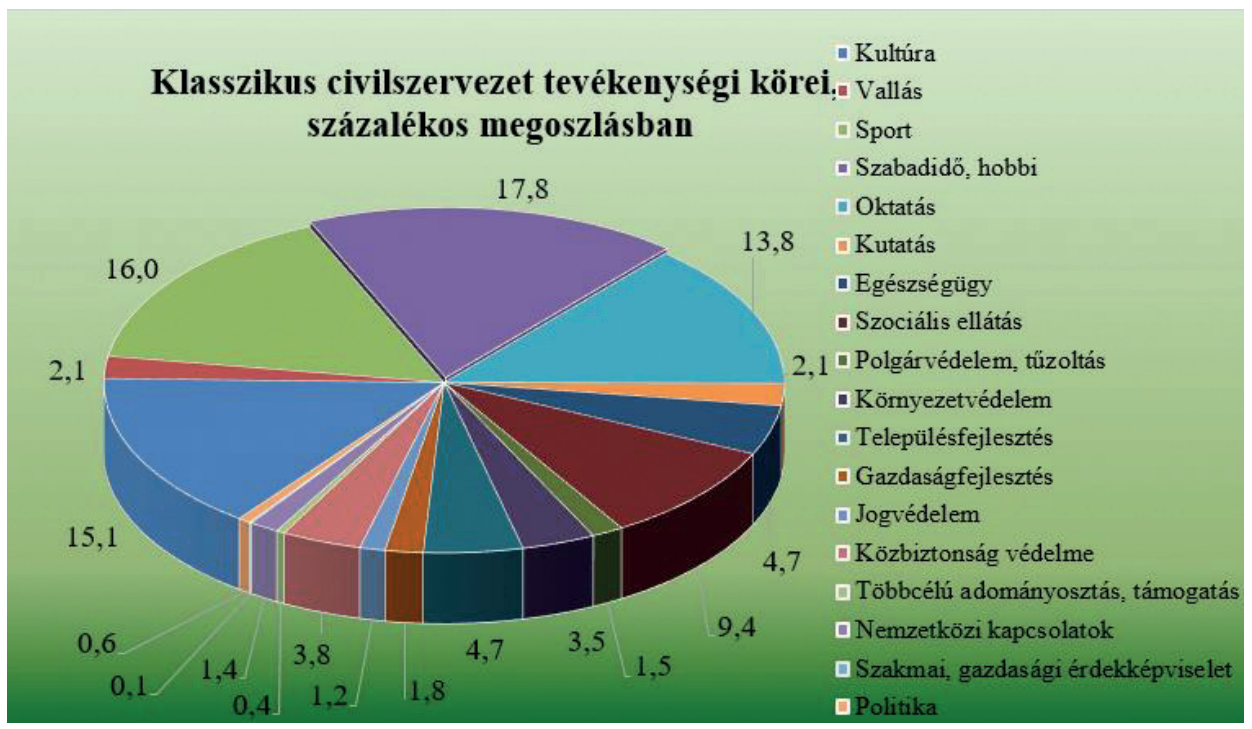

3. ábra: Klasszikus civil szervezet tevékenységi körei százalékos megoszlásban

Forrás: Nonprofit szervezetek Magyarországon, 2015, Adattár, Budapest 2017, 1.4-es táblázat adatai alapján a szerző szerkesztése

58 Kaprinay (2015): i. m. 105. 
A hivatkozott ábrából megállapítható, hogy 2015-ben az 54401 müködő klasszikus civil szervezet többsége a szabadidő eltöltésének aktív és passzív módjához kötődik, hiszen kultúrával 15,1\%, sporttal 16\%, szabadidővel, hobbival pedig a müködő civil szervezetek $17,8 \%$-a foglalkozott.

Az eddigi felvetésekre, a továbbiakban egy szegedi székhelyü civil szervezet jelen tanulmány írásáig elért törekvésein és eredményein keresztül szeretnék olyan válaszlehetőségeket adni, amelyek álláspontom szerint alkalmasak lehetnek a kérdést érintő új, atipikus megoldási irányvonal kialakítására is.

\section{Civilben a fentiek keresztmetszetében ${ }^{59}$}

A 2010-ben alapított szegedi civil szervezet nem mást tűzött ki megvalósítandó céljául, mint hogy a rekreáció területén dolgozó elméleti és gyakorlati szakembereket összefogva olyan értéket közvetítsen minden érdeklődő számára, amely egyrészt képes választ adni a 21. század társadalmi kihívásaira, másrészt megfelelő szakmai-érdekképviseleti szerv is legyen, minden ilyen irányú szakmai program megvalósulására.

Tevékenysége mindezek fényében sokoldalú, mivel igyekszik minél szélesebb körben, minél magasabb szakmai színvonalon kapcsolatot létesíteni, úgy a laikus érdeklődőkkel, mint a tudomány képviselőivel. A hatékony működéshez pedig e két irány teljesen eltérő szakmai alapokon nyugvó megközelítést, követelményrendszert, programlebonyolítást és kommunikációt igényel.

Ennek megfelelően, a továbbiakban a Közép-Kelet-Európai Rekreációs Társaság (a továbbiakban: Társaság) müködésén, valamint a weblapján ${ }^{60}$ közzétett adatain keresztül igyekszem bemutatni azokat a lehetőségeket, amelyeket az egészségfejlesztés, illetve ezen belül a munkahelyi egészségfejlesztés terén egy civil szervezet jelenthet.

\section{A Társaság kapcsolata a tudománnyal}

A Társaság müködésének központi vezérfonala az egészség, amelynek szerepe sajnos a legtöbb ember számára akkor értékelődik fel, amikor az valamilyen oknál fogva már nincs. Az egészségnek rekreációs oldalról történő megértése, vizsgálata, ellenőrzése, valamint a megőrzésével kapcsolatos programok kidolgozása és fenntartása kihívás elé állítja még a kutatókat is. A Társaság közhasznú szervezetként ennek a részese kíván lenni oly módon, hogy a rekreáció és a hozzá tartozó határterületeken keresztül, komplex módon, magas színvonalú, független interdiszciplináris kutatásokat végez. ${ }^{61}$

\footnotetext{
A Közép-Kelet-Európai Rekreációs Társaság hivatalos weblapja, https://recreationcentral.eu/ (Letöltve: 2017. 09. 20.) Uo.

61 Például: GINOP-5.3.4-16 A munkahelyi egészség és biztonság fejlesztése című pályázatban való közreműködés az alábbi pályázatokkal: 1) A foglalkozás-egészségügy és munkabiztonság feladatai és lehetőségei az idősödő munkavállalók aktív életkorának meghosszabbítására a közigazgatás, védelem, kötelezö társadalombiztosítás keretében foglalkoztatottak részére; 2) A foglalkoztatás-egészségügy és munkabiztonság helyzete, szerepe és lehetőségei a Közigazgatás, védelem, kötelezö társadalombiztosítás keretében foglalkoztatottak részére.
} 
E munka eredménye a Társaság tagjainak a számára nemcsak a tudományos életben, hanem a civil szervezetek életében is komoly segítséget tud jelenteni. Így ugyanis az elért tudományos eredmények is sokkal hitelesebben adhatók át a laikus érdeklődők számára.

A tudomány képviselőivel való kapcsolattartás igen sokrétü lehet. Tekintve, hogy a rekreáció területe hazánkban viszonylag új területnek számít, amely az elmúlt évtizedekben indult aktív fejlődésnek, fontos kérdés, hogy a jövő rekreációs szakemberei milyen szakmai alapokkal fognak rendelkezni. A képzés minél szakszerübb eléréséhez a Társasághoz már három megjelent tankönyv köthetö. ${ }^{62}$

Meghatározó szempontot képvisel a tudományos élethez való kötelék vizsgálata során a Társaság szakmai kapcsolati rendszere. Megállapítható, hogy civil szervezetként komoly törekvéseket fektetett a Társaság abba, hogy e követelménynek is megfeleljen, hiszen több hazai és nemzetközi egyetemmel tart fenn tudományos-partneri együttmüködési kapcsolatot.

A Társaság tudományos munkásságának harmadik pillére a Társaság Alapszabálya által deklarált kötelezettsége is egyben. Nevezett alapdokumentum ugyanis elöírja, hogy a Társaság negyedévente köteles a Recreation (jogelődje: rekreacio.eu) elnevezésű tudományos folyóiratot megjelentetni. E szaklap lektorált tanulmányokkal és egyéb, a rekreáció területét érintő színes írásokkal igyekszik a legfrissebb eredményeket, beszámolókat, könyvismertetéseket, valamint egyéb, a rekreációhoz kötődő ismeretterjesztő írásokat megosztani az érdeklődőkkel.

\section{A Társaság kapcsolata az érdeklődőkkel}

Ahhoz, hogy a fent ismertetett törekvések eredményei eljussanak az érdeklődőkhöz, szükség van olyan fórumokra, amelyeken közérthetően megismerteti az elért eredményeket; ezekhez bárki korlátozás nélkül hozzájuthat. Éppen ezért a Társaság fokozott figyelmet fektetetett arra, hogy a tudományos feladatokkal párhuzamosan olyan közösségi hálózatot hozzon létre, amelyen keresztül minél szélesebb réteget minél hatékonyabban tud megszólítani.

Az országban 5 városban ${ }^{63}$ van lehetőség arra, hogy úgynevezett „Életviteli Klubok" keretén belül az érdeklődők díjmentesen megismerkedhessenek az egészségmegörzés, valamint egészségfejlesztés legújabb eredményeivel. Ezeknek a dijmentes, szakmai alapokon nyugvó előadásoknak és társadalmi programoknak a szervezésével a Társaság aktív részt tud vállalni a lakosság életmódjának fejlesztésében is.

Aki szervezett már hasonló értékkel bíró programot, az pontosan tudja, hogy az egyik legnehezebb része egy ilyen rendezvény megszervezésének a hallgatóság létszámának előzetes meghatározása. Ennek elsődleges oka az, hogy nemcsak el kell juttatni a rendezvény tényének a hírét, hanem egyszersmind meg is kell tudni szólítani az érdeklődőket oly módon, hogy önként, a szabadidejük 60-90 percét, gyakoriságtól függően havonta/kéthavonta egyszer erre áldozzák. A korábban bemutatott

62 Megjelent tankönyvek: Fritz (2011): i. m.; Fritz (2015): i. m.; Fritz (2019): i. m.

63 Vö.: A Közép-Kelet-Európai Rekreációs Társaság hivatalos weblapja, https://recreationcentral.eu/ (Letöltve: 2017. 09. 20.) 
szabadidőfelhasználási adatok pedig alátámasztják azt az empirikus tapasztalatot, hogy ez nem egyszerü.

Amennyiben a Társaság 2016-os adataiból indulunk ki, akkor egészen kedvező eredményeket látunk, hiszen ezek alapján megállapítható, hogy 31 programon összesen 2330 fö vett részt ${ }^{64}$, ami átlagban 75 fö/alkalmat jelent. Csakhogy, ha területileg kezdjük el vizsgálni a résztvevők arányát, akkor egyértelmüen megállapítható, hogy a nagyobb látogatottság jellemzően azokon a rendezvényeken volt, ahol szorosabb együttmüködés alakult ki a helyi felsőoktatással. Természetesen fontos, hogy a fiatalok is képviseltetik magukat, de mivel az egészségmegőrzés kérdése nem életkorfüggő, ezért további törekvések szükségesek ahhoz, hogy a laikusok nagyobb létszámban vegyenek részt a vizsgált rendezvényeken.

A Társaság éppen ezért komoly erőfeszítéseket tesz azért, hogy a különböző kommunikációs fórumokon - közösségi média, saját weblap, rádió stb. - is aktívan képviseltesse magát, lehetséges kapcsolatot teremtve valamennyi korosztállyal.

\section{A Társaság lehetőségei a munkahelyi egészségfejlesztés területén}

A munkahelyi egészségfejlesztés megtervezése, megszervezése és lebonyolítása során nagy valószínűséggel sokan a klasszikus gazdasági alapú megoldási lehetőségekben gondolkodnak. Más szavakkal az érdeklődő megbízási jogviszony keretében, ellentételezés fejében egy vállalkozás szolgáltatásait igénybe veszi.

Azonban felmerülhet a kérdés, hogy vajon egy egészségfejlesztéssel foglalkozó civil szervezet, amely mögött már többéves, tudományos alapokon nyugvó szakmai gyakorlat áll, tud-e alternatív lehetőséget jelenteni a vizsgált területen?

A munkahelyi egészségfejlesztés egy szervezet számára több gazdasági potenciált is hordoz magában. Itt ugyanis nem csak arra kell gondolni, hogy például egy vállalati befektetésként kezelt, eredményesen megvalósuló program milyen profitot fog a későbbiekben realizálni azzal, hogy például csökken a táppénzes idő tartama; és/ vagy kisebb mértékben kell gondoskodni a munkavállalók pótlásáról; és/vagy maguk az egészséges munkavállalók válnak motiváltabbá, lelkesebbé, amely már kimutatható hatással van az összteljesítményre.

Egy civil szervezettel való együttmüködés ugyanis magában hordozza a részt vevő vállalat társadalmi felelősségvállalásának további dimenzióit is azzal, ha egy vállalat a munkavállalói fizikai és mentális egészségének megörzéséért szeretne ily módon lépéseket tenni. Farkas Ferencné és Görög Georgina megfogalmazása szerint: „[ha] egy vállalat társadalmilag felelősen, a fenntartható fejlődés elvei betartása mellett szeretne működni, akkor segítség lehet egy non-profit szervezettel való kooperáció, hiszen az elvek és érdekek gyakorlatilag ugyanazok". ${ }^{65}$ Ennek megfelelően például egy egészségfejlesztő program is hatékonyabban végrehajtható, hiszen a cél itt is azonos.

64 A Társaság 2016-os évre vonatkozó közhasznúsági melléklete alapján, Civil szervezetek névjegyzéke, Magyarország Bíróságai, https://birosag.hu/civil-szervezetek-nevjegyzeke (Letöltve: 2017. 09. 20.)

65 Farkas Ferencné - Görög Georgina: Tudatos társadalmi felelősségvállalás a forprofit és a nonprofit szférában, Tudásmenedzsment, 14 (2013/1) 72. http://epa.oszk.hu/02700/02750/00030/pdf/EPA02750_tudasmenedzsment_2013_01_065-075. pdf (Letöltve: 2017. 11. 27.) 
A munkahelyi egészségfejlesztés az egészségfejlesztésnek egy speciális része, ahol fontos szempont a komplex szemléletmód. Ahhoz, hogy egy program sikeres legyen, három eszközrendszernek kell együtt, eredményesen megvalósulnia: (1) a munkaszervezet javítása, (2) az aktív dolgozói részvétel biztosítása és támogatása, valamint (3) az egyéni kompetencia megerősítése.

$\mathrm{Az}$ (1) és a (3) ponthoz eleve adott egy feltétel azzal, hogy a Társaság az egészségfejlesztésben jártas, szakmailag magasan kvalifikált tagokkal, illetve tisztségviselőkkel rendelkezik. A (2) pontban foglaltakat pedig ugyancsak erősíteni tudja az a tény, hogy a cégek/vállalatok és a dolgozóik között a valós szükségleteknek megfeleltethető innovatív kapcsolatot tud a Társaság kialakítani, a rendelkezésre álló szakmai háttér segítségével.

Lényeges érv lehet egy vállalat számára továbbá az is, hogy a jelenleg hatályos jogszabályok alapján egy közhasznú civil szervezetnek meglehetősen komoly kritériumoknak kell megfelelnie. A tény pedig, hogy egy civil szervezet autonóm módon, átláthatóan tud múködni, ugyancsak megfelelö garanciát jelenthet.

Ahhoz, hogy egy mind a két fél számára megfelelő álláspont, úgynevezett winwin helyzet alakuljon ki egy ilyen lehetséges együttműködés során, természetesen több tényezőt is szem előtt kell tartani.

- Mik a vállalat igényei?

- Mekkora részvételi létszámról lenne szó?

- Szükség van-e önkéntesekre? A részt vevő önkéntesek a kérdéses cégtől mozgósíthatók-e, vagy szükség van-e külsős önkéntesek mozgósítására?

- Hogyan tudja támogatni az érdekelt vállalat a kérdéses civil szervezetet?

- Miért éri meg a közremüködőknek civil szervezetként és nem gazdasági alapon, szerződéses partnerként közremüködni egy ilyen program lebonyolításában?

Ezekre a kérdésekre a gyakorlat tud megfelelő választ adni. Az a gazdasági potenciál, amit egy forprofit és egy nonprofit szervezet kölcsönös együttműködése jelenthet, azonban semmiképp sem elhanyagolható mértékü, éppen ezért úgy gondolom, hogy hosszabb távon egy ilyen kooperáció mindenképp kifizetődő vállalkozás lehet.

\section{Következtetések}

Életünk legaktívabb, legkreatívabb időszakát munkahelyünkön töltjük. A szabadidő minél tartalmasabb eltöltésére az aktív korosztálynak, bár igénye lenne, de sok esetben erre ereje nincsen. A mindennapok túlhajszoltsága, kimerültsége azonban csak ideig-óráig tartható. A szabadidő tartalmas eltöltésének szervezése nem feltétlenül az állam feladata. Lehetnek ugyan közszolgáltatások, amelyeknek megszervezésével az állam a tőle elvárható minimumkövetelményeket teljesíti, de ezt a területet jellemzően az egyén, a piac, és a civil szervezetek uralják. Jelen tanulmányomban igyekeztem bemutatni, hogy egy aktív, dolgozó munkavállalónak a szabadidőre szánt ideje a rendelkezésre álló adatok alapján kimutathatóan korlátozott, ez pedig hosszabb távon kimerültséghez, érdektelenséghez, fokozott munkahelyi stresszhez, betegségekhez vezethet. Olyan időszakban azonban, amikor a lelkiismeretes, jól 
dolgozó munkavállaló hosszabb-rövidebb időre történő kiesése is komoly gondot jelent a munkáltató számára, el kell gondolkodni azon, hogy hosszabb távon egy hatékony munkahelyi egészségfejlesztő program megtérülő befektetést jelenthet-e egy vállalat számára. Felismerték ennek szükségességét a Magyar Honvédségen belül is, hiszen egyértelmü törekvések és lépések figyelhetők meg azzal, hogy „a honvédségen belüli preventív medicina arra törekszik, hogy tagjai egészségét ne csak megtartsa, helyreállítsa, hanem szervezetüket edzetté, a terheléseket, megpróbáltatásokat elviselhetővé, a betegségekkel szemben ellenállóvá tegye". ${ }^{66}$ Fritz és szerzőtársainak 2004-es munkája pedig alátámasztja és igazolja egy ilyen befektetés létjogosultságát, ami véleményem szerint irányadó lehet az érdeklődők számára.

A tanulmány elején feltett kérdések vonatkozásában úgy gondolom, hogy egy elsősorban szakmai alapon szerveződő civil szervezet nemcsak hatékony segítséget jelenthet, hanem gazdasági oldalról, akár költségcsökkentő tényezőként is szerepelhet azáltal, hogy elsődleges célja nem profit megszerzése, hanem az általa közvetített értékek minél hatékonyabb módon történő elérése.

\section{Felhasznált irodalom}

Ács Pongrác - Hécz Roland - Paár Dávid - Stocker Miklós: A fittség (m)értéke, Közgazdasági Szemle, 58 (2011/július-augusztus) 689-708. http://unipub.lib. uni-corvinus.hu/440/1/Kszemle_CIKK_1259.pdf (Letöltve: 2017. 09. 20.)

Bajsz Viktória - Sió Eszter - Tóthné Steinhausz Viktória - Karamánné Dr. Pakai Annamária - Császárné Gombos Gabriella: Egy multinacionális cég egészségfelmérése a munkahelyi stressz tükrében, Egészségfejlesztés, 54 (2013/5-6) 40-47.

Bárdosi Mónika - Tabajdi Márta: Kulturálódási szokásaink, Központi Statisztikai Hivatal, Budapest, 2013.

Bucher Eszter: Változó civil társadalom, Nonprofit szervezetek az ezredforduló után, Acta Sociologica: Pécsi Szociológiai Szemle: Szociológiai Tudományos Szemle, 5 (2012/1) 143-150. http://szociologia.btk.pte.hu/sites/default/files/Acta_Sociologia/20_-_ bucher.pdf (Letöltve: 2017. 08. 25.)

Erdőző-Horváth Krisztina: Rekreáció (és) Akadémia, rekreacio.eu, 2 (2012/2) 3.

Falussy Béla: Tevékenységosztályozási rendszerek az időmérleg-vizsgálatokban.

Statisztikai Szemle, 85 (2007/8) 690-714. www.ksh.hu/statszemle_arch ive/2007/2007_08/2007_08_690.pdf (Letöltve: 2017. 11. 14.)

Farkas Ferencné - Görög Georgina: Tudatos társadalmi felelősségvállalás a forprofit és a nonprofit szférában, Tudásmenedzsment, 14 (2013/1) 65-75. http://epa.oszk. hu/02700/02750/00030/pdf/EPA02750_tudasmenedzsment_2013_01_065-075. pdf (Letöltve: 2017. 11. 27.)

Fekete Mariann: Generációs szabadidő-felhasználás képernyőn innen és képernyőn túl az 1999/2000-es és a 2009/2010-es időmérleg-vizsgálat tükrében, Kötő - jelek 2014, 133-159. https://tatk.elte.hu/dstore/document/112/koto_jelek_2014.pdf (Letöltve: 2017. 11. 13.)

66 Vö.: Sótér (2017): i. m. 34. 
Fritz Péter: A rekreáció fogalma, rendszertani felosztása, in: Fritz Péter (szerk.), Alapfogalmak és jelentéseik a rekreáció területén: Rekreáció mindenkinek III., Miskolci Egyetemi Kiadó, Miskolc, 2019.

Fritz Péter - Jakab Ernő - Dorka Péter - Prof. Dr. Mészáros Judit: A munkahelyi egészségfejlesztés európai gyakorlata, Budapesti Népegészségügy 35 (2004/4) 324-330.

Fritz Péter: Mozgásos rekreáció, Bába Kiadó, Szeged, 2011.

Fritz Péter: Szellemi rekreáció, Dialóg Campus Kiadó, Budapest-Pécs, 2015.

Fritz Péter - Schaub Gáborné - Hegedüs Ibolya: Kapcsolat az életmód, szabadidő és rekreáció között, Magyar Sporttudományi Szemle, 8 (2007/2) 52-56. http:// mstt.hu/MSSZ/MSTT_200702.pdf (Letöltve: 2017. 11. 13.)

Galgóczy Gábor: A munkahelyi egészségfejlesztés európai gyakorlata (Bemutatkozik a Munkahelyi Egészségfejlesztés Európai Hálózata), in: Kapás Zsolt (szerk.), Egészséges munkavállaló az egészséges munkahelyeken, A munkahelyi egészségfejlesztés jelene és jövője, Országos Egészségfejlesztési Intézet, Budapest, 2004, 7-13.

Gábor Edina - Kiss Judit: Munkahelyi egészségfejlesztés - a minőség jegyében I., Egészségfejlesztés, 50 (2009/4) 2-8. http://folyoirat.nefi.hu/index.php?journal=Egeszsegfejlesztes\&page=article\&op=view\&path\%5B\%5D=112 (Letöltve: 2017. 09. 20.)

Gyémánt Richárd: Társadalomstatisztika, Pólay Elemér Alapítvány - Szegedi Egyetemi Kiadó, Szeged, 2007.

Időmérleg 2009/2010 Összefoglaló adattár, Központi Statisztikai Hivatal, Budapest, 2012.

Iván László: Az idősödés és időskor, mint az edzettség próbája, in: Némethné Jankovics Györgyi (szerk.), Aktivitás - Mozgás - Sport a harmadik életszakaszban, Szenior könyvek, Győr, 2005, 7-18.

Kaprinay Zsófia: A civil szervezet, mint új fogalmi kategória, és annak lehetséges megközelítései, Miskolci Jogi Szemle, 10 (2015/1) 94-111. www.mjsz.uni-miskolc. hu/201501/8_kaprinayzsofia.pdf (Letöltve: 2017. 11. 13.)

Klinger András: Társadalomstatisztikai alapismeretek, Központi Statisztikai Hivatal, Budapest, 1998.

Kovács Tamás Attila: A rekreáció kultúrája, A rekreáció főbb kulturális alrendszerei, Magyar Sporttudományi Szemle, 8 (2007/2) 13-24. http://mstt.hu/MSSZ/ MSTT_200702.pdf (Letöltve: 2017. 11. 13.)

Nagyváradi Katalin - Kiss-Geosits Beatrix: A munkahely, mint az egészségfejlesztés multiplikációs színtere, Egészségfejlesztés, 52 (2011/3) 14-16.

Nonprofit szervezetek Magyarországon, 2015, Központi Statisztikai Hivatal, Budapest, 2017.1.4-es adattábla, www.ksh.hu/docs/hun/xftp/idoszaki/nonprof/nonprofit_2015.pdf (Letöltve: 2017. 11. 17.)

Sótér Andrea: A munkahelyi egészségfejlesztési tevékenységek rendszerének kialakulása és gyakorlata a Magyar Honvédségben, Honvédorvos, 69 (2017/3-4.) 22-34. http:// real.mtak.hu/93500/1/02\%20A\%20munkahelyi\%20eg\%C3\%A9szs\%C3\%A9gfejleszt\%C3\%A9si\%20tev\%C3\%A9kenys\%C3\%A9g\%20rendszer\%C3\%A9nek\%20kialak\%C3\%ADt\%C3\%A1sa\%20\%C3\%A9s\%20gyakorlata\%20a\%20Magyar\%20Honv\%C3\%A9ds\%C3\%A9gben.pdf (Letöltve: 2020. 03. 26.) 
Statisztikai Tükör: A nonprofit szektor legfontosabb jellemzői, 2015., Budapest, Központi Statisztikai Hivatal, 2016. www.ksh.hu/docs/hun/xftp/stattukor/nonprofit/nonprofit15.pdf (Letöltve: 2017. 09. 20.)

Stocker Miklós - Ács Pongrác: A sportolás növelésével elérhető gazdasági haszon mértéke, Magyar Sporttudományi Szemle 13 (2012/3) 20-26. http://mstt.hu/ MSSZ/MSSZ_201203.pdf (Letöltve: 2017. 11. 15.)

Tibori Tímea: Kulturális magatartás- és értékváltozások, Educatio, 10 (2001/3) 517-529. http://folyoiratok.ofi.hu/sites/default/files/article_attachments/tibor_t_2001_03. pdf (Letöltve: 2017. 11. 15.)

Wansink, Brian: Evés ész nélkül, HVG, Budapest, 2014.

WHO: Health and Development through Physical Activity and Sport, 2003, http:// apps.who.int/iris/bitstream/10665/67796/1/WHO_NMH_NPH_PAH_03.2.pdf (Letöltve: 2017. 08. 29)

\section{Jogi források}

Magyarország Alaptörvénye (2011. április 25.)

2011. évi CLXXV törvény az egyesülési jogról, a közhasznú jogállásról, valamint a civil szervezetek müködéséről és támogatásáról

\section{Internetes források}

Antal Ferenc: Egészségfejlesztés a Magyar Honvédségben, 2019, https://honvedelem. hu/cikk/egeszsegfejlesztes-a-magyar-honvedsegben/ (Letöltve: 2020. 03. 27.) ASICS History, https://corp.asics.com/en/about_asics/history (Letöltve: 2019. 10. 04.) A Közép-Kelet-Európai Rekreációs Társaság hivatalos weblapja: https://recreationcentral.eu/ (Letöltve: 2017. 09. 20.)

Civil szervezetek névjegyzéke, Magyarország Bíróságai, https://birosag.hu/civil-szervezetek-nevjegyzeke (Letöltve: 2017. 09. 20.) 